\title{
De kunst van het voorspellen
}

Mensen zijn geneigd toekomstige beperkingen somberder in te zien dan dat ze daadwerkelijk zijn. In de psychologie heet dat poor affective forecasting, zeg maar het beroerd voorspellen van levenskwaliteit in geval van toekomstige ellende. Neem een patiënt met een vitaal bedreigde diabetische voet. Hij zal veel willen doen om een onderbeenamputatie af te wenden, maar eenmaal toch beland op de operatietafel en nadien bezig met revalideren blijkt het allemaal mee te vallen. Hij pakt zijn leven weer op. Een van de oorzaken van dit beroerde voorspellen is een overmatige focus op negatieve verwachtingen.

Advanced care planning, ofwel vroegtijdige zorgplanning, is hot. Door tijdig zorgwensen en behandelvoorkeuren te bespreken en vast te leggen kan zorg optimaal worden afgestemd op de behoefte van de patiënt. In dit bespreken en vastleggen schuilt echter ook een gevaar. Zo kan bij dementie een te grote focus op verlies van zelfredzaamheid en toenemende afhankelijkheid leiden tot verkeerde beslissingen. In dit nummer nemen Groen et al. ons mee in de gezamenlijke besluitvorming van patiënten met dementie, hun partners, mantelzorgers en zorgverleners om al dan niet deel te nemen aan dagbesteding buitenshuis. Aanvankelijk hebben patiënten met dementie en hun partners slechts negatieve verwachtingen. Denk aan (ik vul in) 'ik wil mijn man niet het huis uit doen' of 'ik ga niet naar een opvang voor demente bejaarden'. Na een fase van het verbreden van perspectieven en het benoemen van positieve verwachtingen gaat de betrokkene dagbesteding uitproberen om vervolgens een goed geïnformeerd besluit te kunnen nemen. Een negatief ingeschatte situatie blijkt bij ervaring juist levenskwaliteit toe te voegen: poor affective forecasting.

Vroegtijdige zorgplanning is van belang op tal van thema's: vergaande chirurgische ingrepen, opnames in ziekenhuis, reanimeerbeleid en beslissingen rond het levenseinde. Steeds is het de kunst om verwachtingen boven tafel te krijgen, focus te verbreden, zoveel mogelijk situaties te laten ervaren en uiteindelijk een goed geïnformeerd gezamenlijk besluit te nemen. Een kunst die de huisarts ten volle beheerst.

Victor van der Meer

Een negatief

ingeschatte situatie

blijkt bij ervaring

juist levenskwaliteit

toe te voegen

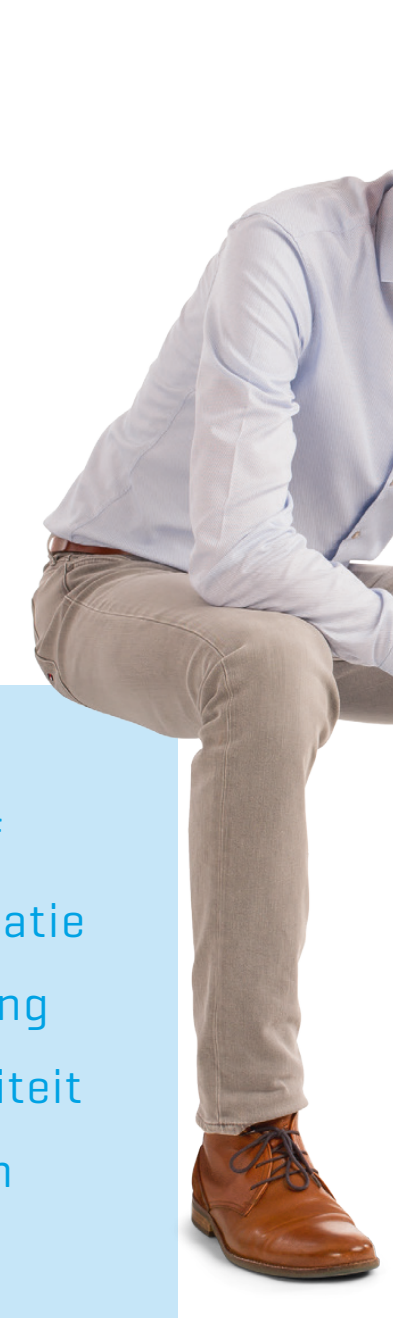

